\title{
Tengsl búsetu fyrstu 20 æviárin við áhættu á sykursýki af tegund 2
}

Elín Ólafsdóttir ${ }^{1,2}$ læknir, Thor Aspelund ${ }^{1,4}$ tölfræðingur, Jóhanna E. Torfadóttir ${ }^{2}$ næringarfræðingur, Laufey Steingrímsdóttir ${ }^{3,5}$ næringarfræðingur, Gunnar Sigurðsson ${ }^{4,5}$ læknir, Bolli Pórsson ${ }^{1}$ læknir, Rafn Benediktsson ${ }^{4,5}$ læknir, Guðný Eiríksdóttir ${ }^{1}$ lífefnafræðingur, Unnur A. Valdimarsdóttir² faraldsfræðingur, Vilmundur Guðnason ${ }^{1,4}$ læknir

\section{ÁGRIP}

Inngangur: Kyrrseta og ofneysla orkuríkrar fæðu tengjast aukinni áhættu á að fá sykursýki af tegund 2 en áhrif ađbúnaðar í uppvexti á slíka áhættu síðar á ævinni hafa lítt verið athuguð. Tilgangur pessarar rannsóknar var að kanna tengsı búsetu í dreifbýli fyrstu 20 æviárin við áhættu á að fá sykursýki 2 miðað við búsetu í Reykjavík frá fæðingu.

Efniviður og aðferðir: I lýðgrunduðu pýði 17.811 karla (48\%) og kvenna, meðalaldur 53 ár (aldursbil 33-81), sem tóku pátt í Reykjavíkurrannsókn Hjartaverndar á árunum 1967-1991, bjuggu 29\% í sveit og 35\% í sjávarporpum að meðaltali i 20 ár áður en peir fluttu til Reykjavíkur, en 36\% bjuggu í Reykjavík frá fæðingu. Reiknuð var hlutfallsleg áhætta á að fá sykursýki 2 eftir búsetu.
Niðurstöður: Hlutfallsleg áhætta á að fá sykursýki 2 var 43\% lægri í körlum (RR 0,57; 95\% Cl 0,43-0,77) og 26\% lægri í konum (RR 0,74; 95\% Cl 0,56-0,99) sem bjuggu í sveit fyrstu 20 ár ævinnar í samanburði við pá sem bjuggu í Reykjavík frá fæðingu. Hið lága algengi meðal peirra sem ólust upp í sveit fannst bæði í aldurshópunum 55-64 ára og 65 ára og eldri.

Ályktanir: Niðurstöður okkar benda til pess að peir sem bjuggu í sveit á fyrri hluta 20. aldar á Íslandi voru í minni hættu á að fá sykursýki 2 síðar á ævinni, en jafnaldrar peirra sem bjuggu í Reykjavík frá fæðingu. Við vörpum fram peirri tilgátu að aðbúnaður snemma á ævinni hafi langvarandi áhrif á sykurefnaskipti líkamans.
${ }^{1}$ Hjartavernd, ${ }^{2}$ Miðstöð ílýðheilsuvísindum, ${ }^{3}$ matvæla- og næringarfræðideild, ${ }^{4}$ læknadeild, Háskóla Íslands, ${ }^{5}$ Landspítala.

\section{Inngangur}

Algengi sykursýki af tegund 2 í sveit og í borg er breytilegt eftir löndum og landsvæðum. Í nýlegum rannsóknum frá Bandaríkjunum ${ }^{1}$, Kanada ${ }^{2}$ og Ástralíu ${ }^{3,4}$ reyndist algengi hærra í sveitum en borgum og var munurinn rakinn að hluta til minni stuðnings frá heilbrigðispjónustu á sumum dreifbýlissvæðum en í borgum. Eldri rannsóknir frá Póllandi sýndu svipaðar niðurstöður, par sem algengi í sveitum var $17,6 \%$ en í péttbýli mældist algengið 14,1\%. ${ }^{5}$ Á Indlandi ${ }^{6}$, i Kína ${ }^{7}$ og ýmsum öðrum löndum Suðaustur-Asíu ${ }^{8}$ hefur algengi sykursýki mælst mjög lágt í dreifbýli en eykst hratt eftir flutning fólks á péttbýlissvæði.

Pótt rannsóknir á áhættupáttum og próun sykursýki 2 hafi einkum beinst að líffræðilegum páttum, hefur félagsleg staða einstaklinga einnig áhrif. Rannsóknarniðurstöður byggðar á gögnum úr sykursýkisskránni frá Skotlandi ${ }^{9}$ sýna að fólk sem bjó par við lökustu lífskjörin var 60\% líklegra til að fá sykursýki 2 heldur en peir sem bjuggu við best lífskjör. Sambærilegar rannsóknir frá Norður-Englandi ${ }^{10}$ sýndu að algengi sykursýki 2 var 30\% hærra meðal einstaklinga sem bjuggu á svæðum sem skoruðu í lægsta fimmtungi á lífsgæðakvarða (deprivation score) miðað við einstaklinga í efsta fimmtungi kvarðans.

Rannsóknir hafa einnig beinst að tengslum lítillar fæðingarpyngdar á áhættu á að fá sykursýki 2 síðar á ævinni. ${ }^{11-13}$ Ýmsar rannsóknir á næringu og vexti ungbarna hafa sýnt fram á tengsl hraðrar pyngdaraukningar á pessu aldursskeiði við aukna áhættu á myndun bæði sykursýki 2 og kransæðasjúkdóma síðar á ævinni. ${ }^{14-16}$
Breytingar á lífsstíl hafa reynst árangursríkar við að tefja og mögulega koma í veg fyrir myndun sykursýki 2 , jafnvel eftir að truflun á sykurstjórnun hefur greinst. ${ }^{17}$ Mikilvægustu pættir í lífsstílsbreytingunum hafa verið aukin hreyfing og líkamleg áreynsla, ásamt mataræðisbreytingu með færri hitaeiningum, sem leiða til lækkunar líkamspyngdar. Reykingar hafa einnig verið tengdar við aukna áhættu á sykursýki $2^{18}$ en rannsóknarniðurstöður um áhrif áfengisneyslu eru misvísandi. ${ }^{19}$

Nokkur munur er talinn hafa verið á umhverfispáttum, eins og mataræði og hreyfingu, til sveita og sjávar samanborið við Reykjavík á fyrri hluta 20. aldar á Íslandi. Börn í sveit tóku pátt í daglegum störfum frá unga aldri og árstíðabundinn matarskortur pekktist. Mataræði var almennt bæði prótein- og fituríkt, en til sveita var meira neytt af mjólk, mjólkurafurðum og kjöti en minna af fiski heldur en í sjávarporpum og í Reykjavík. ${ }^{20-22}$

Rannsóknir á tengslum mismunandi búsetu fyrstu 20 æviárin, en sambærilegri búsetu á fullorðinsárum, við áhættu á sykursýki 2 síðar á ævinni eru ekki auðfundnar. Pví var ákveðið að kanna hversu sterk pessi tengsl væru hjá pátttakendum í Reykjavíkurrannsókn Hjartaverndar um 30 árum eftir búsetuflutning úr dreifbýli til Reykjavíkur og nágrennis.

\section{Efniviður og aðferðir}

Reykjavíkurrannsókn Hjartaverndar var skipulögð sem lýðgrunduð langtíma framvirk hóprannsókn á hjarta- 
Tafla I Algengi sykursýki 2 (SS2) í körlum og konum sem bjuggu í Reykjavík 1967, skoðað eftir búsetu fyrstu 20 æviárin í sveit eða sjávarborpi og i Reykjavík (borg) frá fæðingu. 17.811 einstaklingar fæddir 1907-1935 tóku pátt í rannsókninni á árunum 1967-1991 og var algengið skoðað eftir aldursbilum við komu, en meðalalgengi á sykursýki 2 i hópnum var 3,6\%.

\begin{tabular}{|c|c|c|c|c|}
\hline \multicolumn{2}{|c|}{ Búseta } & Sveit & Sjávarporp & Borg \\
\hline \multicolumn{5}{|c|}{ KARLAR } \\
\hline \multicolumn{2}{|c|}{ Fjöldi án SS2 } & 2415 & 2840 & 2990 \\
\hline \multicolumn{2}{|c|}{ Fjöldi með SS2 } & 72 & 132 & 150 \\
\hline \multicolumn{2}{|c|}{ Aldur í árum ( \pm ) } & $53,7(8,7)$ & $52,2(8,5)$ & $51,2(8,3)$ \\
\hline \multicolumn{2}{|c|}{ Aldursbil } & $34-79$ & $33-78$ & $33-78$ \\
\hline \multicolumn{2}{|c|}{ \% SS2 greind við komu } & 61,5 & 66,7 & 58,5 \\
\hline \multicolumn{2}{|c|}{ Algengi SS2 \% (n) } & $3,0(72)$ & 4,6 (132) & $5,0(150)$ \\
\hline$"$ & á aldrinum $<55$ & 2,3 & 2,8 & 3,6 \\
\hline$"$ & á aldrinum 55-64 & 2,8 & 6,6 & 6,5 \\
\hline \multirow{2}{*}{\multicolumn{2}{|c|}{ á aldrinum 65+ }} & 7,3 & 11,5 & 11,6 \\
\hline & & KONUR & & \\
\hline \multicolumn{2}{|c|}{ Fjöldi án SS2 } & 2635 & 3078 & 3227 \\
\hline \multicolumn{2}{|c|}{ Fjöldi með SS2 } & 73 & 90 & 109 \\
\hline \multicolumn{2}{|c|}{ Aldur í árum ( \pm ) } & $54,2(9,1)$ & $53,5(8,9)$ & $52,3(8,9)$ \\
\hline \multicolumn{2}{|c|}{ Aldursbil } & $33-81$ & $33-80$ & $33-80$ \\
\hline \multicolumn{2}{|c|}{ \% SS2 greind við komu } & 52,1 & 42,7 & 40,2 \\
\hline \multicolumn{2}{|c|}{ Algengi SS2 \% (n) } & $2,8(73)$ & $2,9(90)$ & 3,4 (109) \\
\hline " & á aldrinum $<55$ & 1,2 & 1,5 & 1,5 \\
\hline$"$ & á aldrinum 55-64 & 3,4 & 3,9 & 5,5 \\
\hline$"$ & á aldrinum $65+$ & 7,9 & 7,8 & 9,8 \\
\hline
\end{tabular}

og æðasjúkdómum á Íslandi. Í desember 1966 voru 30.795 karlar og konur, fædd 1907-1935, skráð íbúar í Reykjavík og nágrenni. Valið var 27.281 manna slembiúrtak úr pessum hópi og boðið til pátttöku í rannsókninni en afgangurinn hafður sem viðmið. Rannsóknarpýðinu var skipt í 6 hópa sem rannsakaðir voru í 6 áföngum eins og lýst hefur verið í fyrri greinum. ${ }^{23,24}$ Alls páðu 19.381 boð um pátttöku, eða 71\%. Í núverandi rannsókn eru notuð gögn úr fyrstu 5 áföngum Reykjavíkurrannsóknarinnar sem safnað var á árunum 1967 til 1991.

Pátttakendur greindu frá búsetustöðum frá fæðingu, par sem peir höfðu dvalið í 5 ár eða lengur. Pótt allir pátttakendur byggju í Reykjavík og nágrenni 1967, voru 64\% peirra fædd annars staðar og höfðu búið að meðaltali i 20 ár (staðalfrávik 8 ár og fjórðungsmörk 15-24 ár) utan Reykjavíkur áđur en peir fluttu á höfuðborgarsvæðið. Öll sveitarfélög utan Reykjavíkur og nágrennis voru flokkuð ýmist sem sveit eða sjávarporp með hliðsjón af korti Landmælinga Íslands um hreppa-, sýslu- og kjördæmaskiptingu frá 1974. Alls var 245 sveitarfélögum skipt í fjóra flokka: Reykjavík og nágrenni, sjávarporp, sveit og loks blandaða sveita- og sjávarbyggð eins og pegar hefur verið lýst ítarlega á öðrum vettvangi. ${ }^{22}$ Í greiningu okkar á tengslum búsetu við algengi sykursýki 2 undanskildum við 1061 pátttakanda, sem bjuggu á svæðum sem flokkuð höfðu verið sem blönduð sveita- og sjávarbyggð. Rannsóknarhópurinn samanstóð pví af 17.811 körlum og konum (meðalaldur 53 ár, aldursbil 33-81) og af peim bjuggu 5195 (29\%) í sveit að meðaltali í 20 ár áður en pau fluttu á höfuðborgarsvæðið, 6140 (35\%) bjuggu í sjávarporpum fyrstu 20 ár ævinnar en 6476 (36\%) í Reykjavík frá fæðingu.
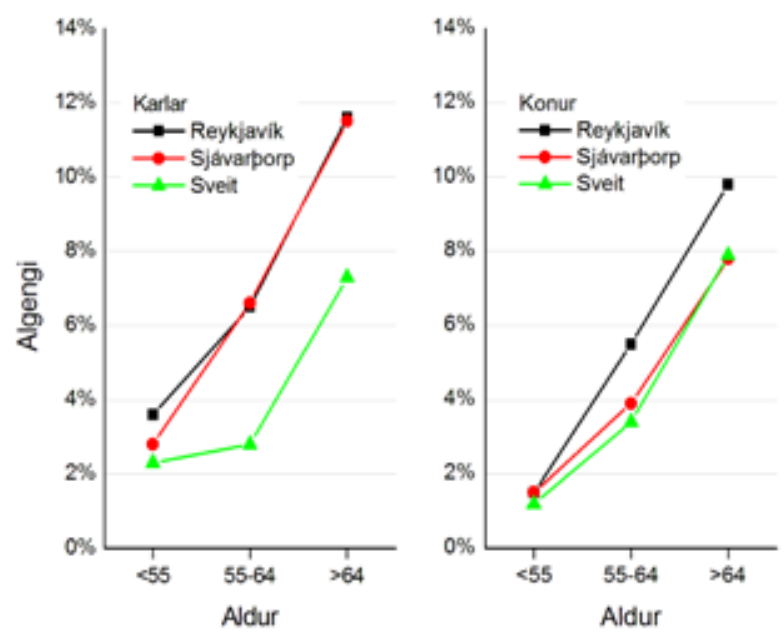

Mynd 1. Algengi sykursýki 2 í körlum (a) og konum (b) sem bjuggu í Reykjavík 1967, flokkað eftir aldursbili við komu í Reykjavíkurrannsóknina og búsetu fyrstu 20 ár ævinnar, í sveit (29\%), í sjávarporpi (35\%) eða í Reykjavík (36\%) frá fæðingu.

Sykursýki 2 var greind samkvæmt skilmerkjum Alpjóðaheilbrigðismálastofnunarinnar, WHO, frá 199925, sem eru ýmist fastandi glúkósi í sermi $\geq 7 \mathrm{mmol} / 1$ við komu, frásögn um sykursýki samkvæmt spurningalista og/eða notkun sykurlækkandi lyfja.

Blóðsýni voru tekin að morgni eftir næturlanga föstu. Eftirtalin efni voru mæld í sermi: heildarkólesteról, HDL-kólesteról, príglýseríð og glúkósi. Efnin voru mæld á COBAS Mira efnagreini og notuð prófefni frá Roche Diagnostics samkvæmt leiðbeiningum frá framleiðanda.

Blóðprýstingur var mældur með kvikasilfursblóðprýstingsmæli (mercury sphygmomanometer) og meðaltal tveggja mælinga notað. Нæð og pyngd var ákvörðuð og líkamspyngdarstuðull (body mass index, BMI) reiknaður sem $\mathrm{kg} / \mathrm{m}^{2}$.

Pátttakendur svöruðu við komu spurningum um hversu oft peir stunduðu miðlungs eða mikla líkamsrækt í frístundum. Svör voru flokkuð í aldrei, sjaldan, stöku sinnum, miðlungs eða oft. Við skiptum svörunum í tvíhliða breytu, pað er í stöku sinnum til oft og aldrei eða sjaldan. Önnur spurning um pátttöku í ípróttum á aldrinum 20-29 ára var einnig skoðuð.

Svör við menntun voru einnig flokkuð sem tvíhliða breyta: menntun upp að framhaldsskóla eða minna og framhaldsmenntun og viðbótarmenntun eftir pað.

Pátttakendur svöruðu ítarlegum spurningalistum um heilsufar og félagslega stöðu við komu í rannsóknina. Peir sem luku ekki við spurningalistann eða skiluðu ófullkomnum mælingum voru ekki teknir með. Pátttakendur sem greindu frá tilkomu sykursýki fyrir 40 ára aldurinn voru ekki heldur teknir með til að útiloka pá sem mögulega höfðu greinst með sykursýki af tegund 1.

Gerður var samanburður á grunnmælingum pátttakenda eftir kyni og búsetu fyrstu 20 æviárin með pví að nota ýmist línulega eða logistíska aðhvarfsgreiningu með aldursaðlögun. Breytur með skekkta dreifingu voru yfirfærðar á log-skala. Poisson-aðhvarfslíkan (regression model) var notað til að meta hlutfallslega áhættu (relative risk, $R R$ ) á að fá sykursýki 2. Við útreikninga á hlutfallslegri áhættu var leiðrétt fyrir aldri, líkamspyngdarstuðli, príglýseríðum, slagbilsprýstingi, reykingum, menntun, hreyfingu í frístundum og aðkomu í áfanga rannsóknarinnar á mismunandi tíma. Tölfræðileg marktækni var ákvörðuð með tvíhliða t-prófi 
miðað við 5\% líkindi. Tölfræðiforritið SAS/STAT ${ }^{\circledast}$, útgáfa 9.2 var notað við útreikninga á rannsóknargögnum.

Leyfi Persónuverndar og Vísindasiðanefndar (VSN: 00-063) liggja fyrir.

\section{Niðurstöður}

Í lýðgrunduðu pýði 17.811 karla og kvenna (meðalaldur 53 ár, aldursbil 33-81), sem tóku pátt í Reykjavíkurrannsókn Hjartaverndar, hafði rúmlega priðjungur búið á höfuðborgarsvæðinu frá fæðingu. Rétt undir priðjungi bjó í sveit og priðjungur við sjávarsíðuna, að meðaltali í um 20 ár áđur en flutt var til Reykjavíkur og nágrennis. Algengi sykursýki 2, ákvarðað með hliðsjón af búsetu fyrstu 20 ár ævinnar, er sýnt í töflu I. Af körlum sem ólust upp í sveit voru 3\% með sykursýki 2 við komu í Reykjavíkurrannsóknina miðað við $5 \%$ peirra sem bjuggu á höfuðborgarsvæðinu frá fæðingu. Meðal kvenna sem ólust upp í sveit var algengið 2,8\% miðað við 3,4\% peirra sem bjuggu í Reykjavík frá fæðingu. Hlutfallsleg áhætta (RR) á að fá sykursýki 2 var 43\% lægri (RR 0,57; 95\% CI 0,43-0,77) í körlum og 26\% lægri (RR 0,74; 95\% CI 0,56-0,99) í konum sem ólust upp í sveit miðað við búsetu í Reykjavík frá fæðingu, eftir að leiðrétt hafði verið fyrir aldri, príglýseríðum, líkamspyngdarstuðli og slagbilsprýstingi, sjá töflu II. Áhættumunurinn var marktækt meiri hjá körlum en konum $(\mathrm{p}=0,0008)$. Viðbótarleiðréttingar vegna reykinga, menntunar, hreyfingar í frístundum og aðkomu í rannsóknina á mismunandi tíma höfðu lítil áhrif á áhættuna. Pegar skoðuð er hlutfallsleg áhætta miðað við búsetu í sjávarporpi fyrstu 20 ár ævinnar og í Reykjavík frá fæðingu, er ekki tölfræðilega marktækur munur á áhættu meðal karla. Meðal kvenna sem bjuggu í sjávarporpi er áhættan svipuð og hjá peim sem bjuggu í sveit, og reyndist 23\% lægri en meðal jafnaldra peirra sem bjuggu á höfuðborgarsvæðinu frá fæðingu, eftir að leiðrétt hafði verið fyrir aldri, príglyseríðum, líkamspyngdarstuðli og slagbilsprýstingi, eins og sjá má í töflu II. Pessi munur er pó ekki tölfræðilega marktækur $(\mathrm{p}=0,059)$.

Til að kanna hvort pessi munur á algengi héldist með hækkandi aldri, var búsetuhópunum skipt í prjú aldursbil, í <55 ára, 55-64
Tafla II. Hlutfallsleg áhætta á að fá sykursýki 2 (a) eftir búsetu í sveit fyrstu 20 æviárin miðað við búsetu i Reykjavík og nágrenni frá fæðingu, (b) eftir búsetu í sjávarporpi fyrstu 20 æviárin miðað við búsetu í Reykjavík og nágrenni frá fæðingu. 95\% vikmörk eru sýnd ásamt áhættuminnkun i \% og p-gildi.

\begin{tabular}{|c|c|c|c|c|c|c|}
\hline & & & \multicolumn{2}{|c|}{ 95\% vikmörk } & \multicolumn{2}{|c|}{ Áhættuminnkun } \\
\hline & Líkan & $\mathrm{RR}$ & Neðri & Efri & $\%$ & p-gildi \\
\hline Karlar (a) & 1 & 0,52 & 0,39 & 0,69 & 48 & $<0,0001$ \\
\hline \multirow[t]{3}{*}{ Sveit/Reykjavík } & 2 & 0,57 & 0,43 & 0,77 & 43 & 0,0002 \\
\hline & 3 & 0,56 & 0,42 & 0,76 & 44 & 0,0001 \\
\hline & 4 & 0,57 & 0,43 & 0,77 & 43 & 0,0002 \\
\hline Karlar (b) & 1 & 0,87 & 0,68 & 1,09 & 13 & 0,2138 \\
\hline \multirow{3}{*}{$\begin{array}{l}\text { Sjávarporp/ } \\
\text { Reykjavík }\end{array}$} & 2 & 0,91 & 0,72 & 1,16 & 9 & 0,4497 \\
\hline & 3 & 0,91 & 0,72 & 1,16 & 9 & 0,4415 \\
\hline & 4 & 0.91 & 0.71 & 1,15 & 9 & 0,4289 \\
\hline Konur (a) & 1 & 0,70 & 0,52 & 0,93 & 30 & 0,0154 \\
\hline \multirow[t]{3}{*}{ Sveit/Reykjavík } & 2 & 0,74 & 0,56 & 0,99 & 26 & 0,0435 \\
\hline & 3 & 0,75 & 0,56 & 1,00 & 25 & 0,0555 \\
\hline & 4 & 0,76 & 0,57 & 1,02 & 24 & 0,0710 \\
\hline Konur (b) & 1 & 0,78 & 0,59 & 1,02 & 22 & 0,0765 \\
\hline \multirow{3}{*}{$\begin{array}{l}\text { Sjávarporp/ } \\
\text { Reykjavík }\end{array}$} & 2 & 0,77 & 0,59 & 1,01 & 23 & 0,0594 \\
\hline & 3 & 0,78 & 0,59 & 1,03 & 22 & 0,0760 \\
\hline & 4 & 0,78 & 0,60 & 1,03 & 22 & 0,0782 \\
\hline
\end{tabular}

Líkan1: Aðlagað fyrir aldri.

Líkan 2: Aðlagað fyrir aldri, BMI, slagbilsprýstingi og príglýseríðum í sermi.

Líkan 3: Aðlagað til viðbótar fyrir reykingum, menntun og hreyfingu í frístundum.

Líkan 4: Aơlagað til viðbótar fyrir áfanga rannsóknar.

ára og >64 ára, og algengið ákvarðað eins og sýnt er á mynd 1 og í töflu I. Algengi sykursýki 2 meðal karla sem ólust upp við sjávarsíðuna og í Reykjavík er nánast pað sama í hópunum eldri en 55 ára og er næstum tvisvar sinnum hærra en meðal karla sem ólust upp í sveit. Í aldurshópunum eldri en 55 ára var algengi sykursýki 2 meðal kvenna sem ólust upp í sveit og við sjávarsíðuna svipað og töluvert lægra en meðal kvenna sem ólust upp í Reykjavík.

Grunnmælingar sem gerðar voru við komu í rannsóknina eru sýndar í töflu III. Meðalaldur var 53 ár, en karlar og konur sem

Tafla III. Grunnmælingar við komu i Reykjavíkurrannsóknina (1967-1991) samkvæmt búsetu í sveit, í sjávarporpi eða borg (Reykjavík) fyrstu 20 ár ævinnar.

\begin{tabular}{|c|c|c|c|c|c|c|}
\hline \multirow[b]{2}{*}{ Breytur } & \multicolumn{3}{|c|}{ Karlar } & \multicolumn{3}{|c|}{ Konur } \\
\hline & Sveit & Sjávarporp & Borg & Sveit & Sjávarporp & Borg \\
\hline Fjöldi & 2487 & 2972 & 3140 & 2708 & 3168 & 3336 \\
\hline Aldur í árum ( \pm ) & $53,6(8,7)$ & $52,3(8,6)^{\star \star \star}$ & $51,3(8,3)^{\star \star \star}$ & $54,2(9,2)$ & $53,5(8,9)^{\star}$ & $52,4(8,9)^{\star \star \star}$ \\
\hline Kólesteról, mmol/L ( \pm ) & $6,36(1,07)$ & $6,43(1,07)^{\star}$ & $6,35(1,07)$ & $6,65(1,22)$ & $6,69(1,26)^{\star}$ & $6,51(1,21)^{\star \star}$ \\
\hline Príglýseríð, mmol/L, miðgildi (IQR) & $1,03(0,65)$ & $1,09(0,67)^{\star \star \star}$ & $1,14(0,71)^{\star \star \star}$ & $0,90(0,51)$ & $0,92(0,54)^{\star \star \star}$ & $0,93(0,56)^{\star \star \star}$ \\
\hline Glúkósi, mmol/L ( \pm ) & $5,36(0,85)$ & $5,40(0,87)^{\star}$ & $5,46(0,94)^{\star \star \star}$ & $5,12(0,78)$ & $5,18(0,83)^{\star \star}$ & $5,18(0,89)^{\star \star \star}$ \\
\hline $\mathrm{BMI}, \mathrm{kg} / \mathrm{m}^{2}( \pm)$ & $25,6(3,3)$ & $25,7(3,4)$ & $26,0(3,6)^{\star \star \star}$ & $25,0(4,3)$ & $25,2(4,3)$ & $25,1(4,3)^{\star}$ \\
\hline Slagbilsprýstingur, mm Hg ( \pm ) & $140,2(19,2)$ & $139,6(18,7)$ & $140,9(19,5)^{\star \star \star}$ & $137,3(20,8)$ & $138,2(20,9)^{\star}$ & $136,6(20,2)$ \\
\hline Hlébilsprýstingur, mm Hg ( $( \pm)$ & $88,1(10,3)$ & $87,9(10,1)$ & $88,6(10,8)^{\star}$ & $84,0(10,2)$ & $84,3(10,3)$ & $84,0(10,1)$ \\
\hline Algengi kransæðasjúkdóma† \% & 2,9 & 3,1 & 2,6 & 0,5 & $0,9^{*}$ & $0,8^{*}$ \\
\hline Reykingar við komu \% & 49,6 & $56,7^{\star \star \star}$ & $59,3^{\star * \star}$ & 38,5 & 38,0 & $44,1^{\star \star *}$ \\
\hline Framhaldsmenntun $\%$ & 23,7 & $20,2^{\star \star \star}$ & $21,8^{\star}$ & 8,1 & $6,3^{\star \star}$ & $10,8^{\star \star \star}$ \\
\hline Pátttaka i ípróttum 20-29 ára \% & 17,0 & 15,3 & $21,3^{\star \star \star}$ & 7,7 & 7,6 & $10,7^{\star \star \star}$ \\
\hline Hreyfing í frístundum við komu \% & 11,9 & $10,0^{*}$ & $13,8^{*}$ & 10,0 & 11,4 & $14,4^{\star \star \star}$ \\
\hline
\end{tabular}

Tölfræðileg marktækni: * $p<0,05 ;{ }^{* *} p<0,01 ;{ }^{* \star \star} p<0,001$ fyrir aldursaðlagaðan samanburð, búseta í sveit notað sem viðmið. BMI=líkamspyngdarstuðull.

†Algengi samkvæmt sögu um kransæðastíflu (MI), blásningu (PCI) og hjáveituaðgerðir (CABG) í sjúkraskrám. 


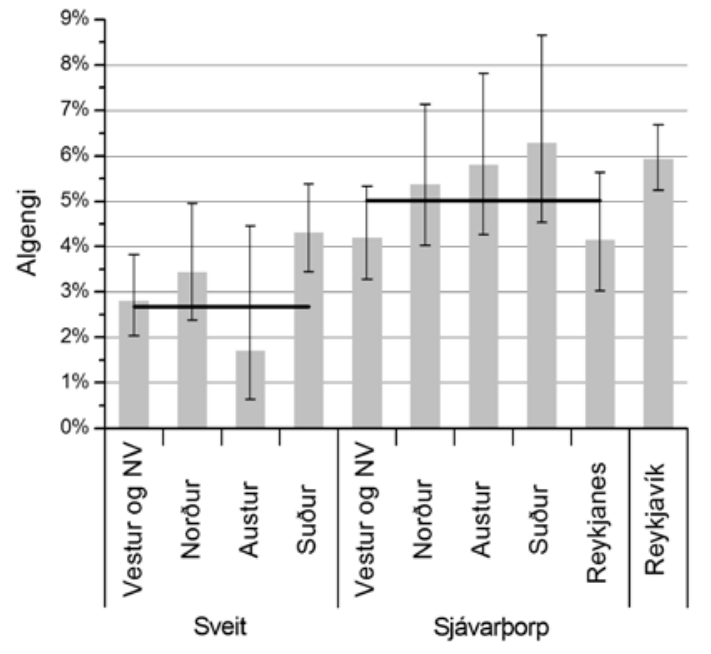

Mynd 2. Algengi sykursýki 2 íkörlum (48\%) og konum, sem bjuggu í Reykjavík 1967, skipt eftir búsetu í mismunandi landshlutum fyrstu 20 ár ævinnar; aðlagað er fyrir kyni og aldri (60 ára). Láréttu línurnar sýna aðlagað meðalalgengi peirra sem ólust upp í sveit (2,7\%) og sjávarporpi (5\%). Vikmörk eru sýnd fyrir hverja súlu (95\% CI) og fjöldinn að baki peirra er pessi:

Úr sveit (heildarfjöldi 5195): Vestur- og Norðvesturland (1640), Norðurland (1002), Austurland (290), Suðurland (2263). Úr sjávarporpum (heildarfjöldi 6140): Vesturog Norðvesturland (1918), Norðurland (1233), Austurland (935), Suðurland (743), Reykjanes (1311). Búsettir í Reykjavík frá fæðingu (6476).

ólust upp í sveit voru heldur eldri að meðaltali en einstaklingar í hinum hópunum tveimur. Gildi príglýseríða, líkamspyngdarstuðuls og slagbilsprýstings voru heldur hærri í körlum sem bjuggu í Reykjavík og nágrenni frá fæðingu en peirra sem komu úr sveit, og reykingar voru algengari bæði meðal karla og kvenna sem bjuggu par frá fæðingu. Menntunarstig var ápekkt í öllum búsetuhópum og voru yfir $20 \%$ karla með framhaldsmenntun. Konur voru með talsvert lægra menntunarstig en karlar, sérstaklega pær sem bjuggu við sjávarsíðuna fyrstu 20 ár ævinnar, en í peim hópi voru $6 \%$ með framhaldsmenntun miðað við 10,8\% kvenna sem bjuggu á höfuðborgarsvæðinu frá fæðingu.

Lífsskilyrði voru vissulega ólík eftir héruðum landsins á fyrri hluta 20. aldar og pví var ákveðið að kanna algengi sykursýki 2 eftir búsetu á mismunandi landssvæðum til sjávar og sveita eins og sýnt er á mynd 2. Ekki var skipt hér eftir kynjum, en leiðrétt fyrir aldri og kyni. Áberandi munur fannst á algengi sykursýki 2 meðal fólks sem ólst upp í sveit á austanverðu landinu miðað við pá sem bjuggu í sveit á Suðurlandi fyrstu 20 ár ævinnar. Munurinn á algengi sykursýki 2 eftir búsetu við sjávarsíðuna á mismunandi landsvæðum er ekki eins mikill, pótt algengi væri lægra meðal fólks frá Reykjanesi, Vesturlandi og Vestfjörðum en peirra sem komu frá sjávarsíðunni norðan-, austan- og sunnanlands, par sem algengið var nánast pað sama og meðal peirra sem bjuggu í Reykjavík og nágrenni frá fæðingu.

\section{Umræða}

Helstu niðurstöður voru pær að karlar sem ólust upp í sveit voru í 43\% lægri áhættu á að fá sykursýki 2 síðar á ævinni miðað við að hafa búið í Reykjavík og nágrenni frá fæðingu. Konur sem ólust upp í sveit voru í 26\% lægri áhættu á að fá sykursýki 2 síðar á ævinni miðað við jafnöldrur sem bjuggu í Reykjavík frá fæðingu. Enginn áhættumunur greindist meðal karla sem bjuggu fyrstu 20 árin í sjávarporpi miðað við í Reykjavík, en meðal kvenna var algengið nánast pað sama meðal peirra sem ólust upp í sjávarporpi og í sveit og var umtalsvert lægra en peirra sem bjuggu í Reykjavík frá fæðingu, pótt munurinn næði ekki tölfræðilegri marktækni. Mögulega var aðbúnaður karla sem bjuggu í sjávarporpum ápekkur pví sem gerðist í Reykjavík, meðan karlar í sveit á sama tíma bjuggu við annan kost. Aðbúnaður kvenna í sveit og við sjávarsíðuna virðist samkvæmt pessum tilgátum hafa verið svipaður.

Engar sambærilegar erlendar rannsóknir á langtímaáhrifum búsetu í uppvexti á algengi sykursýki 2 hafa fundist. Flestar rannsóknir á algengi eru pverskurðarrannsóknir par sem skoðað er algengi á sama tíma í borg og dreifbýli og hafa pær sýnt að víða í Norður-Ameríku ${ }^{1,2}$, Ástralíu ${ }^{3,4}$ og Evrópu ${ }^{5}$ er algengi sykursýki hærra í dreifbýli, en á svæðum í Suðaustur-Asíu ${ }^{6-8}$ er pessu öfugt farið. Pennan mun má að líkindum rekja til gjörólíks aðbúnaðar fólks í dreifbýli í iðnaðarsamfélögum og í peim löndum sem enn stunda landbúnað að gömlum sið.

Pegar algengi var kannað með tilliti til búsetu í mismunandi landshlutum reyndist pað lægst meðal einstaklinga sem ólust upp í sveit á austanverðu landinu. Við skoðuðum einnig algengi eftir landshlutum með pví að sameina hópa sem höfðu búið í sveit og við sjávarsíðuna og reyndist algengi sykursýki vera lægst meðal einstaklinga sem komu frá Vesturlandi og Vestfjörðum. Nærtækustu skýringarnar á pessum mun eru mismunur á umhverfisaðstæðum og afkomu einstaklinga á umræddum landsvæðum á peim tíma sem pátttakendur í rannsókninni voru að alast upp. Erfðafræðilegar upplýsingar um svæðisbundna einangrun innan landsvæða á árunum 1910-1935 liggja einnig fyrir. ${ }^{26}$ Mismunandi erfðaeiginleikar gætu skýrt að hluta mögulegt viðnám gegn myndun sykursýki 2 eða aukna áhættu af erfðafræðilegum grunni og væri áhugavert að kanna pað nánar.

Munurinn á grunnmæligildum pátttakenda í búsetuhópunum á miðjum aldri var ekki nægilega mikill til að skýra pennan mikla mun á algengi sykursýki milli búsetuhópa. Hlutfallsleg áhætta var til dæmis nánast sú sama eftir að leiðrétt hefur verið fyrir gildum á príglýseríðum, líkamspyngdarstuðli og slagbilsprýstingi og til viðbótar reykingum, menntun, hreyfingu í frístundum og aðkomu í rannsóknina á mismunandi tíma. Menntunarstig var svipað meðal karla í öllum hópum, sem bendir til að lítill munur sé á pjóðfélagsstöðu milli búsetuhópa. Ásókn í frekari menntun kann að hafa verið einn af hvötunum til búsetuflutninga, pótt eftirsókn eftir ábatasamri vinnu hafi einnig verið mikilvægur páttur.

Mismunandi fæðuframboð og neysluvenjur er annar mikilvægur páttur sem kann að skýra pennan mun á algengi sykursýki 2 milli búsetuhópa. Mikilvægustu upplýsingar sem við höfum um mismunandi neysluvenjur til sveita og sjávar er rannsókn Manneldisráðs Íslands sem var gerð árið 1939-1940, ${ }^{20}$ á tíma pegar stór hluti af rannsóknarhópnum var að flytja á höfuðborgarsvæðið. Mestur var munurinn á neyslu mjólkur og mjólkurafurða, en neysla peirra var tvöfalt meiri á sveitaheimilum heldur en við sjávarsíðuna og í Reykjavík. Meira kjötmeti og slátur en minni fiskur var á borðum fólks til sveita en í Reykjavík. Hlutfall fitu var einnig hærra í sveitum og hitaeiningafjöldi meiri á sveitaheimilum en í Reykjavík (meðalhitaeiningar karla voru 3553 á dag miðað 
við 3090 í Reykjavík). ${ }^{20}$ Pessi munur á hitaeininganeyslu kann að skýrast af meiri orkupörf par sem erfiðisvinnan var almennari og stöðugri en í péttbýli.

Í öldrunarrannsókn Hjartaverndar var spurningalisti um matarvenjur lagður fyrir undirhóp úr rannsóknarhópnum okkar. Par var spurt um hversu oft tilteknar matartegundir voru á boðstólum á aldrinum 14-19 ára og eins á miðjum aldri, en unnt var að bera svörin saman við ítarlega mataræðiskönnun sem gerð var á vegum Manneldisráðs Íslands 1990 meðal miðaldra fólks. ${ }^{27}$ Niðurstöðurnar sýndu að upplýsingar um pað hversu oft helstu fæðutegunda var neytt endurspegla vel neyslu aðalfæðuflokkanna og duga vel til rannsókna á tengslum tiltekinna fæðutegunda og ákveðinna sjúkdóma. Ein áhugaverð niðurstaða úr spurningalistanum um matarvenjur var að $44 \%$ karla sem ólust upp í sveit nefndu að peir hefðu ekki fengið nóg að borða á aldrinum 14-19 ára miðað við $34 \%$ karla sem ólust upp í Reykjavík. Af konum sem ólust upp í sveit voru 30\% sem sögðust ekki hafa fengið nóg en $20 \%$ kvenna sem bjuggu í Reykjavík frá fæðingu. ${ }^{28}$

Upplýsingar um mataræði Íslendinga gegnum tíðina liggja í gögnum um heildarframboð matvæla, bæði úr innflutningsskýrslum og yfirliti yfir framleiðslu til sveita og sjávar ásamt öðrum sögulegum gögnum. ${ }^{21}$ Pessi gögn sýna að mataræði pjóðarinnar breyttist gríðarlega frá seinni hluta 19. aldar og fram á miðja 20. öld. Á pessu tímabili breyttist samsetning fæðunnar frá pví að vera að meirihluta dýraafurðir yfir í að verða að meirihluta korn og grænmeti, auk pess sem neysla á hvítu hveiti og sykri jókst jafnt og pétt. Fæðuframboð á Íslandi á pessum tíma var töluvert ólíkt pví sem var í nágrannalöndum okkar. Breytingin á mataræði í Evrópu frá pví að vera að meirihluta dýraafurðir yfir í kornmeti að meirihluta er talin hafa byrjað á 16. öld, en neysla dýraafurða var tekin að aukast aftur vegna bættra samgangna og aukinnar velmegunar á seinni hluta 19. aldar. Pað verður pó að hafa í huga að gögn um fæðuframboð eru heildargögn fyrir alla pjóðina en sýna ekki mun eftir landshlutum eða efnahag heimila. Gögn um fæðuframboð sýna pó vel hver meðalneysla íbúanna hefur verið á hverjum tíma og pað er athyglisvert að sjá hvernig orkuneysla minnkaði við lok heimsstyrjaldarinnar fyrri og aftur í kreppunni upp úr 1930, sem fer vel saman við samdrátt 1 efnahagslífi Íslendinga á peim árum. ${ }^{21}$ Mikilvægar upplýsingar um samsetningu á kornvöruneyslu má einnig sjá í gögnum um innflutning á kornvöru frá 1900 til 1940, par sem innflutningur á rúgi og byggi dróst verulega saman en jókst að sama skapi á hvítu hveiti og haframjöli. ${ }^{21}$

Pótt erfiðisvinna og mikil hreyfing hafi verið algeng á öllum búsetusvæðum landsins pegar pátttakendur í rannsókninni voru að alast upp, má ætla að almennt vinnuálag til sveita hafi verið meira en í péttbýli. Bæði konur og karlar unnu mikið, purftu að ganga langar vegalengdir milli staða og börn byrjuðu snemma að taka til hendi. Trúlega hafa ungir drengir hreyft sig meira en stúlkur og unnið líkamlega erfiðari störf, sem gæti útskýrt að hluta muninn á verndandi áhrifum sveitabúsetu milli kynja. Hið lága algengi á sykursýki á Íslandi, sem tók ekki að hækka fyrr en upp úr 1950, kann að stafa af aðbúnaði sem landsmenn bjuggu almennt við fram yfir 1940. ${ }^{29}$

Aðalstyrkur rannsóknarinnar er pátttaka hlutfallslega stórs hluta pjóðarinnar sem fæddur var 1907-1935 og ítarlegar upplýsingar um búsetu peirra frá fæðingu. Helstu veikleikar eru fátæklegar upplýsingar um mataræði einstaklinganna og skortur á nákvæmum upplýsingum um annan aðbúnað í uppvexti. Ennfremur kann uppvöxtur í sveit að hafa mótað annars konar lífsmynstur eftir flutning til Reykjavíkur, sem kann að hafa haft áhrif í pá veru að draga úr áhættu á að fá sykursýki 2 eða fresta pví að sjúkdómurinn kæmi fram, pótt fyrirliggjandi gögn bendi ekki til pess.

\section{Lokaoro}

Niðurstöður pessarar rannsóknar sýna að einstaklingar sem bjuggu í sveit fyrstu 20 æviárin á fyrri hluta síðustu aldar, voru í minni áhættu á að fá sykursýki 2 síðar á ævinni en jafnaldrar peirra sem bjuggu í Reykjavík frá fæðingu. Pessi tengsl voru til staðar eftir lengri en 30 ára búsetu á höfuðborgarsvæðinu og voru sterkari í körlum en konum. Mismunandi aðbúnaður, bæði hvað varðar vinnuálag og fæðuframboð með mögulegum árstíðabundnum fæðuskorti, sem var meiri í sveit en borg, kann að skýra pessi verndandi áhrif gegn sykursýki 2. Tilgáta okkar er sú að mótandi áhrif á sykurbúskap af völdum umhverfisins á fyrstu 20 árum ævinnar haldist fram á efri ár og skýri að hluta pessi tengsl.

Fram á miðja síðustu öld var algengi sykursýki 2 mjög lágt á Íslandi en hefur farið vaxandi síðan. Af pví sem hér hefur verið kynnt má ætla að aðbúnaður frá unga aldri hafi áhrif á heilsufar út ævina og geti haft áhrif á tilkomu langvinnra sjúkdóma eins og sykursýki 2 á síðari æviárum. Рað er umhugsunarvert hvort fyrirbyggjandi aðgerðir purfi ekki að ná betur til pess borgarumhverfis sem við búum börnum og ungu fólki í dag, með skilningi á mikilvægi aukinnar hreyfingar og hollra neysluvenja. Til að ná árangri purfa allir að taka höndum saman, vandamálið er pjóðfélagslegt, pekkingin er til staðar og brýnt að nýta hana öllum til hagsbóta.

\section{Pakkir}

Höfundar pakka öllum pátttakendum fyrir framlag peirra til rannsóknarinnar. Rannsóknin var kostuð af Rannsóknarstöð Hjartaverndar. 


\section{Heimildir}

1. Krishna S, Gillespie KN, McBride TM. Diabetes burden and access to preventive care in the rural United States. J Rural Health 2010; 26: 3-11.

2. Public Health Agency of Canada. phac-aspc.gc.ca/publicat/2009/ndssdic-snsddac-09/index-eng.php - október 2009 .

3. Wan $\mathrm{Q}$, Harris MF, Powell-Davies G, Jayasinghe UW, Flack J, Georgiou A, et al. Cardiovascular risk levels in general practice patients with type 2 diabetes in rural and urban areas. Aust J Rural Health 2007; 15: 327-33.

4. Wan Q, Harris MF, Davies GP, Jayasinghe UW, Flack J, Georgiou A, et al. Cardiovascular risk management and its impact in Australian general practice patients with type 2 diabetes in urban and rural areas. Int J Clin Pract 2008; 62 53-8.

5. Lopatynski J, Mardarowicz G, Nicer T, Szczesniak G, Krol H, Matej A, et al. [The prevalence of type II diabetes mellitus in rural urban population over 35 years of age in Lublin region (Eastern Poland)]. Pol Arch Med Wewn 2001; 106: 781-6.

6. Misra P, Upadhyay RP, Misra A, Anand K. A review of the epidemiology of diabetes in rural India. Diabetes Res Clin Pract 2011; 92: 303-11.

7. Pan C, Shang S, Kirch W, Thoenes M. Burden of diabetes in the adult Chinese population: a systematic literature review and future projections. Int J Gen Med 2010; 3: 173-9.

8. Rahim MA, Hussain A, Azad Khan AK, Sayeed MA Keramat Ali SM, Vaaler S. Rising prevalence of type 2 diabetes in rural Bangladesh: a population based study. Diabetes Res Clin Pract 2007; 77: 300-5.

9. Evans JM, Newton RW, Ruta DA, MacDonald TM, Morris AD. Socio-economic status, obesity and prevalence of Type 1 and Type 2 diabetes mellitus. Diabet Med 2000; 17: $478-80$
10. Connolly V, Unwin N, Sherriff P, Bilous R, Kelly W. Diabetes prevalence and socioeconomic status: a population based study showing increased prevalence of type 2 diabetes mellitus in deprived areas. J Epidemiol Community Health 2000; 54: 173-7.

11. Forsen T, Eriksson J, Tuomilehto J, Reunanen A, Osmond C, Barker D. The fetal and childhood growth of persons who develop type 2 diabetes. Ann Intern Med 2000; 133: 176-82.

12. Birgisdottir BE, Gunnarsdottir I, Thorsdottir I, Gudnason $\mathrm{V}$, Benediktsson R. Size at birth and glucose intolerance in a relatively genetically homogeneous, high-birth weight population. Am J Clin Nutr 2002; 76: 399-403.

13. Ong KK, Dunger DB. Birth weight, infant growth and insulin resistance. Eur J Endocrinol 2004; 151 Suppl 3: U131-9.

14. Eriksson JG, Forsen TJ, Osmond C, Barker DJ. Pathways of infant and childhood growth that lead to type 2 diabetes. Diabetes Care 2003; 26: 3006-10.

15. Eriksson JG. Epidemiology, genes and the environment lessons learned from the Helsinki Birth Cohort Study. J Intern Med 2007; 261: 418-25.

16. Dunger DB, Salgin B, Ong KK. Session 7: Early nutrition and later health early developmental pathways of obesity and diabetes risk. Proc Nutr Soc 2007; 66: 451-7.

17. Mozaffarian D, Kamineni A, Carnethon M, Djousse L Mukamal KJ, Siscovick D. Lifestyle risk factors and newonset diabetes mellitus in older adults: the cardiovascular health study. Arch Intern Med 2009; 169: 798-807.

18. Willi C, Bodenmann P, Ghali WA, Faris PD, Cornuz J. Active smoking and the risk of type 2 diabetes: a systematic review and meta-analysis. JAMA 2007; 298: 2654-64.

19. Djousse L, Biggs ML, Mukamal KJ, Siscovick DS. Alcoho consumption and type 2 diabetes among older adults: the Cardiovascular Health Study. Obesity (Silver Spring) 2007; 15: $1758-65$.
20. Sigurjonsson J. Mataræði og heilsufar á Íslandi. Manneldisráð, Reykjavík: 1943.

21. Jonsson G. Changes in Food Consumption in Iceland, 1770-1940. Scandinavian Economic History Review 1998; 46: $24-41$

22. Torfadottir JE, Steingrimsdottir L, Mucci L, Aspelund T, Kasperzyk JL, Olafsson $\mathrm{O}$, et al. Milk intake in early life and risk of advanced prostate cancer. Am J Epidemiol 2012; 175 : 144-53.

23. Jonsdottir LS, Sigfusson N, Sigvaldason $\mathrm{H}$, Thorgeirsson G. Incidence and prevalence of recognised and unrecognised myocardial infarction in women. The Reykjavík Study. Eur Heart J 1998;19(7):1011-8.

24. Sigurdsson E, Thorgeirsson G, Sigvaldason H, Sigfusson N. Prevalence of coronary heart disease in Icelandic men 1968-1986. The Reykjavík Study. Eur Heart J 1993; 14: 584-

25. WHO. Definition, diagnosis and classification of diabetes mellitus and its complications: report of a WHO consultation. Part 1, Diagnosis and classification of diabetes mellitus. World Health Organization, Department of Noncommunicable Disease Surveillance, Genf 1999.

26. Helgason A, Yngvadottir B, Hrafnkelsson B, Gulcher J, Stefansson K. An Icelandic example of the impact of population structure on association studies. Nat Genet 2005; 37: 90-5.

27. Eysteinsdottir T, Gunnarsdottir I, Thorsdottir I, Harris T, Launer LJ, Gudnason V, et al. Validity of retrospective diet history: assessing recall of midlife diet using food frequency questionnaire in later life. J Nutr Health Aging 2011; 15: 809-14.

28. Torfadóttir JE. Dietary habits across the lifespan and risk of prostate cancer. A population-based study in Iceland. Doktorsritgerð, Háskóla Íslands 2012. skemman.is/ handle/1946/13227 - nóvember 2012.

29. Albertsson V. Diabetes in Iceland. Diabetes 1953; 2: 184-6.

\section{ENGLISH SUMMARY}

\section{Early life residency associated with the risk of developing type 2 diabetes - The population-based Reykjavík Study}

Olafsdottir $\mathrm{E}^{1,2}$, Aspelund $\mathrm{T}^{1,4}$, Torfadottir $\mathrm{JE}^{2}$, Steingrimsdottir $\mathrm{L}^{3,5}$, Sigurdsson $\mathrm{G}^{4,5}$, Thorsson $\mathrm{B}^{1}$, Benediktsson $\mathrm{R}^{4,5}$, Eiriksdottir $\mathrm{G}^{1}$,

Valdimarsdottir UA ${ }^{2}$, Gudnason $V^{1,4}$

Introduction: Sedentary lifestyle and energy rich food have been associated with the risk of developing type 2 diabetes; limited data are available on environmental conditions in childhood on this risk later in life. The objective was to study if residency in the first 20 years of life affected the risk of developing type 2 diabetes.

Methods: In a cohort of 17811 men (48\%) and women, mean age 53 years (range 33-81) participating in the population-based Reykjavík Study from 1967-91, 29\% grew up in rural and 35\% in coastal areas for an average of 20 years before moving to urban Reykjavík, but $36 \%$ lived in Reykjavík from birth. The prevalence of type 2 diabetes according to residency in early life was examined.
Results: The relative risk of developing type 2 diabetes was $43 \%$ lower in men (RR 0.57; 95\% Cl 0.43-0.77) and 26\% lower (RR 0.74; $95 \% \mathrm{Cl}$ 0.56-0.99) in women living in rural areas for the first 20 years of their life compared with those living in urban Reykjavík from birth. The low prevalence among those that grew up in rural areas was maintained through the age categories of 55-64 years and 65 years and older.

Conclusions: Our findings indicate that persons growing up in rural areas in early $20^{\text {th }}$ century lceland had lower risk of developing type 2 diabetes later in life when compared with peers living in Reykjavík from birth. We postulate a prolonged effect of early development on glucose metabolism and risk of developing type 2 diabetes.

Key words: Cohort study, type 2 diabetes, rural area, urban area, long term risk evaluation of type 2 diabetes, Reykjavik Study.

Correspondence: Vilmundur Guð̋nason, v.gudnason@hjartavernd. is

${ }^{1 /} / \mathrm{celandic}$ Heart Association, ${ }^{2} \mathrm{Center}$ of Public Health Sciences, ${ }^{3}$ Faculty of Food Science and Nutrition, ${ }^{4}$ Faculty of Medicine, University of Iceland, ${ }^{5}$ Landspitali University Hospital 